\title{
SCIDiC
}

\author{
International Journal of Dentistry and Oral Science (IJDOS) \\ ISSN: 2377-8075
}

\section{Prevalence And Gender Association Among Different Types Of Nasolabial Angles}

Research Article

John Rozar Raj ${ }^{1}$, Nivethigaa . B $^{*}$, Nivedhitha M.S $S^{3}$

${ }^{1}$ Saveetha Dental College and Hospitals, Saveetha Institute of Medical and Technical Sciences, Chennai - 600 077, TN, India.

${ }^{2}$ Senior Lecturer, Department of Orthodontics, Saveetha Dental College, Saveetha Institute of Medical and Technical Sciences, Saveetha University, 162, Poonamallee High Road, Chennai - 600077, Tamil Nadu, India.

${ }^{3}$ Professor, Department of Conservative Dentistry \& Endodontics, Saveetha Dental College, Saveetha Institute of Medical and Technical Sciences, Saveetha University, 162, Poonamallee High Road, Chennai - 600077, Tamil Nadu, India.

Abstract

\begin{abstract}
Various pre-treatment soft tissue analyses have always been used to determine facial aesthetics, thus offering an important diagnostic tool to clinicians. A frequently used soft tissue parameter in orthodontic diagnosis is the nasolabial angle. The nasolabial angle is defined as the angle between the line drawn through the midpoint of the nostril aperture and a line drawn perpendicular to the Frankfurt horizontal while intersecting subnasale. This study was done to determine the prevalence and gender association of different types of nasolabial angles. This was a retrospective study. Samples were collected from the patient record archive from a private dental institution and used for the purpose of the study. Data of different types of nasolabial angles were collected for patients of all the age groups. Excel tabulation was done and SPSS results were obtained. In the present study, the prevalence of straight nasolabial angle was $95 \%$, prevalence of acute nasolabial angle was $4 \%$ and the prevalence of obtuse nasolabial angle was $1 \%$ and the results were statistically significant $(\mathrm{p}<0.05)$. From the present study, we can conclude that the prevalence of straight nasolabial angles was more common in both male and female population and among various age groups when compared to acute and obtuse nasolabial angles.
\end{abstract}

Keywords: Nasolabial Angle; Nasolabial Fold; Orthodontic Diagnosis; Orthodontic Treatment Planning.

\section{Introduction}

In orthodontics, various pre-treatment soft tissue analyses have always been used to determine facial aesthetics, thus offering an important diagnostic tool to clinicians. A frequently used soft tissue parameter in orthodontic diagnosis is the nasolabial angle. Nasolabial angle is defined as the angle between the line drawn through the midpoint of the nostril aperture and a line drawn perpendicular to the Frankfort horizontal plane while intersecting subnasale. Studies on facial profile have demonstrated that facial balance should have been obtained if a proportional relationship between the nose, upper lip and chin exists. Thus the nasolabial angle becomes a clinical and cephalometric parameter for the determination of soft tissue profile alterations. The nasolabial angle is formed by two lines, one from the nose, another from the upper lip and both independent of each other. The angular measure- ment described by these two lines is a resultant of the individual inclinations. The nasolabial angle of a person may be within the normal range. Small or large the measurement of this angle alone provides inadequate information as it does not reveal which component is responsible for the variability. It could be the nose, lip or both. Therefore, it is important to analyze each component of the angle to assist in the differential diagnosis of normal from its variation. Fitzgerald [1] developed a new method of constructing the nasolabial angle $[2,3]$. There are three types of nasolabial angles: straight, acute and obtuse. An arbitrary range of 90 to 120 degrees is stated as the ideal nasolabial angle [4]. When the nasolabial angle is over 130 degrees, the nasolabial angle is described as obtuse nasolabial angle, while an angle of 90 degrees or less is described as an acute nasolabial angle. An acute nasolabial angle can cause airway interference. It can be seen in patients with repaired cleft lip and palate who experienced some horizontal and

\section{*Corresponding Author:}

Nivethigaa .B,

Senior Lecturer, Department of Orthodontics, Saveetha Dental College, Saveetha Institute of Medical and Technical Sciences, Saveetha University, 162, Poonamallee High Road, Chennai - 600077, Tamil Nadu, India.

Tel: 9791972324

E-mail: nivedhigaab.sdc@saveetha.com

Received: May 28, 2021

Accepted: June 16, 202

Published: July 03, 2021

Citation: John Rozar Raj, Nivethigaa .B, Nivedhitha M.S. Prevalence And Gender Association Among Different Types Of Nasolabial Angles. Int J Dentistry Oral Sci. 2021;8(7):30023005. doi: http://dx.doi.org/10.19070/2377-8075-21000611

Copyright: Nivethigaa. $\mathbf{B}^{\circ}$ 2021. This is an open-access article distributed under the terms of the Creative Commons Attribution License, which permits unrestricted use, distribution and reproduction in any medium, provided the original author and source are credited. 
vertical collapse of the maxilla. The obtuse nasolabial angle is often seen with anteroposterior maxillary deficiency. Generally, the more obtuse the nasolabial angle, the more prominent the nostrils become. It can even cause a gummy smile and lip competence. Nasolabial between 90 to 120 degrees is considered more aesthetic $[5,6]$. Thus the nasolabial angle plays a very important role in orthodontic diagnosis and aesthetics.Previously our team has a rich experience in working on various research projects across multiple disciplines [7-21]. This study was done to determine the prevalence and gender association of different types of nasolabial angles.

\section{Materials And Methods}

This was a retrospective study. The study setting was a university setting. Ethical approval was obtained from the Institutional ethical committee(SDC/SIHEC/DIASDATA/0619-0320). Samples were collected from the patient record archive from a private dental institution and used for the purpose of the study. Cross verification was done with another examiner to avoid any missing data values .Sampling bias was minimised by including all available data without any sorting process. Data of different types of nasolabial angles were collected for patients of all the age groups and entered in a methodological manner. Excel Tabulation and SPSS importing was done. Incomplete data were excluded from the study. Independent variables were age and gender. Dependent variable was types of nasolabial angles. Data was analyzed using SPSS software (IBM SPSS Statistics, Version 24.0, Armonk, NY: IBM Corp]. Chi-square test was performed to find the association between the variables. The level for a statistical significance was set at $\mathrm{p}<0.05$.

\section{Results And Discussion}

In this study, out of 41,190 patients, 23930 were males and 17251 were females. Higher prevalence of straight nasolabial angle was seen in the population under all age groups with the percentage of $95 \%$, acute nasolabial angle was seen with the percentage of $4 \%$ and obtuse nasolabial angle was seen the least with the percentage of 1\% (Figure 1). Straight nasolabial angles were distributed more commonly among all the age groups. Acute nasolabial angle was distributed more between the age group of 19-35 years. Obtuse nasolabial angle was found lesser than the other two types of nasolabial angle. In the study done by Owen.et.al [22], the nasolabial angle was reported to be small in younger patients. In the study done by Nanda.et.al [23], they reported that the nasolabial angle changes little after 7 years. The nasolabial angle decreased slightly from 7 to 18 years of age in both the sexes with the mean being $107.8^{\circ}$ for boys and $114^{\circ}$ for girls. At 18 years, the means were 105.8 for men and $110.7^{\circ}$ for women.

Higher prevalence of straight nasolabial angles was seen among both male and female population compared to other forms ( Figure 2) and the results obtained were statistically significant. Straight nasolabial angles were distributed more in male patients. Acute and obtuse nasolabial angles were distributed equally in both male and female patients. In the study done by Fitzgerald. et.al [1], No statistical significance was seen between men and women, but the women did have a slightly larger nasolabial angle. But in our study, there was statistical significance. In the study done by Kommi.et.al [24], No statistically significant difference was observed between male and female, but males recorded a

Figure 1. Bar chart depicts the prevalence of different types of nasolabial angles in different age groups. $\mathrm{X}$-axis denotes age groups. Y-axis denotes the number of patients with different forms of nasolabial angle. (Chi-square test, $p$ value- 0.001 ; $(<0.05)$ hence statistically significant). Higher prevalence of straight nasolabial angles (Blue) was seen in the population under all age groups, compared to acute(green) and obtuse(beige) nasolabial angle and the results obtained were found to be statistically significant.

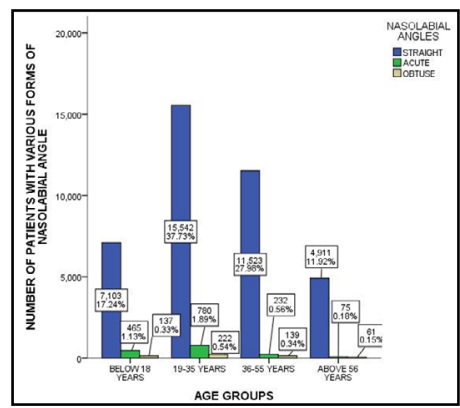

Figure 2. Bar chart depicts the gender distribution of different forms of nasolabial angle. X-axis denotes different forms of nasolabial angle and $\mathrm{Y}$-axis denotes the number of patients in each category. (Chi-square test, $\mathrm{p}$ value- $0.001(<0.05$, hence statistically significant). Higher prevalence of straight nasolabial angles was seen among both male(red) and female(purple) populations compared to other forms and the results obtained were statistically significant.

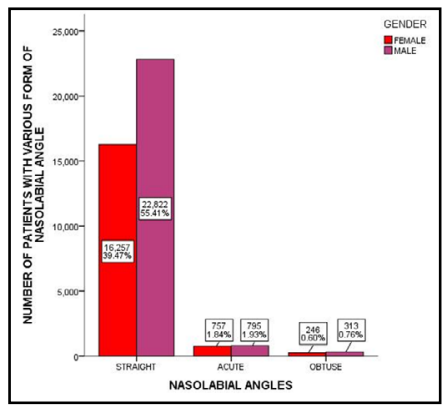


more obtuse nasolabial angle of $101.73^{\circ}$ and females recorded a nasolabial angle of $98^{\circ}$. In the study done by Vinay. et.al [25], Males had shown higher nasolabial angle values in comparison to females in the Indian population. Various other studies have demonstrated that soft tissues which vary considerably in thickness are a major factor in determining a patient's profile [26, 27]. This study showed about the different types of nasolabial angles and it's efficiency in orthodontic diagnosis and treatment planning. Our institution is passionate about high quality evidence based research and has excelled in various fields [28-38].

The findings of the present study add to the consensus of the previous study. Smaller sample size could not provide results of the entire population. So future studies can be done with a larger sample size. Factors like all age groups can be considered. Different types of nasolabial angles and its association with malocclusion can be analysed.

\section{Conclusion}

From the present study, we can conclude that the prevalence of straight nasolabial angles $(95 \%)$ was more compared to acute $(4 \%)$ and obtuse(1\%) nasolabial angle. Gender and age association revealed that in the population studied, the presence of straight nasolabial angle was seen more in both the gender and in all the age groups. Thus greater emphasis needs to be placed on their evaluation in formulating treatment plans for dentofacial disharmonies. Multicentric studies should be done to establish the norms as well as prevalence in various populations.

\section{Author Contributions}

All authors have equal contribution in bringing out this research work.

\section{Acknowledgement}

The study was supported by Saveetha Dental College and Hospitals who provided insights and expertise that greatly assisted the study. We could also like to thank the reviewers of the article for their insights.

\section{References}

[1]. Fitzgerald JP, Nanda RS, Currier GF. An evaluation of the nasolabial angle and the relative inclinations of the nose and upper lip. Am J Orthod Dentofacial Orthop. 1992 Oct 1;102(4):328-34.

[2]. Lo FD. Changes in nasolabial angle due to maxillary incisor retraction Am J Orthod Dentofacial Orthop. 1982 Jan 1;81(1):81.

[3]. Singh RN. Changes in the soft tissue chin after orthodontic treatment. J Orthod Dentofacial Orthop. 1990 Jul 1;98(1):41-6.

[4]. Armijo BS, Brown M, Guyuron B. Defining the ideal nasolabial angle. Plast Reconstr Surg. 2012 Mar 1;129(3):759-64.

[5]. Meyer R, Berset J-C, Emeri J-F, Simmen D. Nasolabial Angle and Upper Lip. Secondary Rhinoplasty. 2002:275-93. Available from: http://dx.doi. org/10.1007/978-3-642-56267-9_27

[6]. Garcia C, Olivi P. Nasolabial angle and orthognathic surgery. Int. Orthod. 2015;13:43-60. Available from: http://dx.doi.org/10.1016/j.ortho.2014.12.015

[7]. Hafeez N. Accessory foramen in the middle cranial fossa. Res J Pharm Technol. 2016 Nov 1;9(11):1880.

[8]. Krishnan RP, Ramani P, Sherlin HJ, Sukumaran G, Ramasubramanian A, Jayaraj G, et al. Surgical Specimen Handover from Operation Theater to Laboratory: A Survey. Ann Maxillofac Surg. 2018 Jul-Dec;8(2):234-238. Pubmed PMID: 30693238
[9]. Somasundaram S, Ravi K, Rajapandian K, Gurunathan D. Fluoride Content of Bottled Drinking Water in Chennai, Tamilnadu. J Clin Diagn Res. 2015 Oct;9(10):ZC32-4.Pubmed PMID: 26557612.

[10]. Felicita AS, Sumathi Felicita A. Orthodontic extrusion of Ellis Class VIII fracture of maxillary lateral incisor - The sling shot method . Saudi Dent J. 2018;30: 265-9. Available from: http://dx.doi.org/10.1016/j. sdentj.2018.05.001

[11]. Kumar S, Rahman RE. Knowledge, awareness, and practices regarding biomedical waste management among undergraduate dental students. Asian J Pharm Clin Res. 2017;10(8):341.

[12]. Gurunathan D, Shanmugaavel AK. Dental neglect among children in Chennai. J Indian Soc Pedod Prev Dent. 2016 Oct 1;34(4):364.

[13]. Sneha S. Knowledge and awareness regarding antibiotic prophylaxis for infective endocarditis among undergraduate dental students. Asian J Pharm Clin Res. 2016 Oct 1:154-9.

[14]. Dhinesh B, Lalvani JI, Parthasarathy M, Annamalai K. An assessment on performance, emission and combustion characteristics of single cylinder diesel engine powered by Cymbopogon flexuosus biofuel. Energy Convers. Manag. 2016 Jun 1;117:466-74.

[15]. Choudhari S, Thenmozhi MS. Occurrence and Importance of Posterior Condylar Foramen. LATERALITY. 2016 Aug 28;8:11-43.

[16]. Paramasivam A, Vijayashree Priyadharsini J, Raghunandhakumar S. N6adenosine methylation $(\mathrm{m} 6 \mathrm{~A})$ : a promising new molecular target in hypertension and cardiovascular diseases. Hypertens Res. 2020 Feb;43(2):153154.Pubmed PMID: 31578458.

[17]. Wu F, Zhu J, Li G, Wang J, Veeraraghavan VP, Krishna Mohan S, et al. Biologically synthesized green gold nanoparticles from Siberian ginseng induce growth-inhibitory effect on melanoma cells (B16). Artif Cells Nanomed Biotechnol. 2019 Dec;47(1):3297-3305.Pubmed PMID: 31379212.

[18]. Palati S, Ramani P, Shrelin HJ, Sukumaran G, Ramasubramanian A, Don KR, et al. Knowledge, Attitude and practice survey on the perspective of oral lesions and dental health in geriatric patients residing in old age homes. Indian J Dent Res. 2020 Jan-Feb;31(1):22-25.Pubmed PMID: 32246676.

[19]. Saravanan M, Arokiyaraj S, Lakshmi T, Pugazhendhi A. Synthesis of silver nanoparticles from Phenerochaete chrysosporium (MTCC-787) and their antibacterial activity against human pathogenic bacteria. Microb Pathog. 2018 Apr;117:68-72.Pubmed PMID: 29427709.

[20]. Govindaraju L, Gurunathan D. Effectiveness of Chewable Tooth Brush in Children-A Prospective Clinical Study. J Clin Diagn Res. 2017 Mar;11(3):ZC31-ZC34.Pubmed PMID: 28511505.

[21]. Vijayakumar Jain S, Muthusekhar MR, Baig MF, Senthilnathan P, Loganathan S, Abdul Wahab PU, et al. Evaluation of Three-Dimensional Changes in Pharyngeal Airway Following Isolated Lefort One Osteotomy for the Correction of Vertical Maxillary Excess: A Prospective Study. J Maxillofac Oral Surg. 2019 Mar;18(1):139-146.Pubmed PMID: 30728705.

[22]. Owen 3rd AH. Diagnostic block cephalometrics. Part 1. J Clin Orthod. 1984 Jun 1;18(6):400-22.

[23]. Nanda RS, Meng H, Kapila S, Goorhuis J. Growth changes in the soft tissue facial profile. Angle Orthod. 1990 Sep;60(3):177-90.

[24]. Kommi PB, Venkatesan R, Keerthi N, Kumar AN, Kumar S, Gopinath V. A cephalometric assessment of ideal nasolabial angle range for south Indian population. J. Int. Oral Health. 2016 Feb 1;8(2):205.

[25]. Dua V, Gupta S, Singh C. Evaluation of the nasolabial angle in the Indian population. Contemporary clinical dentistry. $2010 \mathrm{Apr} ; 1(2): 79$.

[26]. Alharethy S. Preferred nasolabial angle in Middle Eastern population. Eur Arch Otorhinolaryngol. 2017 May;274(5):2339-2341.Pubmed PMID: 28243784.

[27]. Ramesh Kumar KR, Shanta Sundari KK, Venkatesan A, Chandrasekar S. Depth of resin penetration into enamel with 3 types of enamel conditioning methods: a confocal microscopic study. Am J Orthod Dentofacial Orthop. 2011 Oct;140(4):479-85.Pubmed PMID: 21967934.

[28]. Vijayashree Priyadharsini J. In silico validation of the non-antibiotic drugs acetaminophen and ibuprofen as antibacterial agents against red complex pathogens. J Periodontol. 2019 Dec;90(12):1441-1448.Pubmed PMID: 31257588.

[29]. PC J, Marimuthu T, Devadoss P, Kumar SM. Prevalence and measurement of anterior loop of the mandibular canal using CBCT: A cross sectional study. Clin Implant Dent Relat Res. 2018 Apr 6;20(4):531-4.

[30]. Ramesh A, Varghese S, Jayakumar ND, Malaiappan S. Comparative estimation of sulfiredoxin levels between chronic periodontitis and healthy patients - A case-control study. J Periodontol. 2018 Oct;89(10):1241-1248.Pubmed PMID: 30044495.

[31]. Ramadurai N, Gurunathan D, Samuel AV, Subramanian E, Rodrigues SJ. Effectiveness of 2\% Articaine as an anesthetic agent in children: randomized controlled trial. Clin Oral Investig. 2019 Sep;23(9):3543-50.

[32]. Sridharan G, Ramani P, Patankar S, Vijayaraghavan R. Evaluation of salivary metabolomics in oral leukoplakia and oral squamous cell carcinoma. J Oral 
Pathol Med. 2019 Apr;48(4):299-306.

[33]. Ezhilarasan D, Apoorva VS, Ashok Vardhan N. Syzygium cumini extract induced reactive oxygen species-mediated apoptosis in human oral squamous carcinoma cells. J Oral Pathol Med. 2019 Feb;48(2):115-121.Pubmed PMID: 30451321.

[34]. Mathew MG, Samuel SR, Soni AJ, Roopa KB. Evaluation of adhesion of Streptococcus mutans, plaque accumulation on zirconia and stainless steel crowns, and surrounding gingival inflammation in primary molars: randomized controlled trial. Clin Oral Investig. 2020 Sep;24(9):1-6.Pubmed PMID: 31955271

[35]. Samuel SR. Can 5-year-olds sensibly self-report the impact of developmental enamel defects on their quality of life? Int J Paediatr Dent. 2021 Mar;31(2):285-286.Pubmed PMID: 32416620.
[36]. R H, Ramani P, Ramanathan A, R JM, S G, Ramasubramanian A, et al. CYP2 C9 polymorphism among patients with oral squamous cell carcinoma and its role in altering the metabolism of benzo[a]pyrene. Oral Surg Oral Med Oral Pathol Oral Radiol. 2020 Sep;130(3):306-312.Pubmed PMID: 32773350 .

[37]. Chandrasekar R, Chandrasekhar S, Sundari KKS, Ravi P. Development and validation of a formula for objective assessment of cervical vertebral bone age. Prog Orthod. 2020 Oct 12;21(1):38.Pubmed PMID: 33043408.

[38]. Vijayashree Priyadharsini J, Smiline Girija AS, Paramasivam A. In silico analysis of virulence genes in an emerging dental pathogen A. baumannii and related species. Arch Oral Biol. 2018 Oct;94:93-98.Pubmed PMID: 30015217. 